\title{
Social media marketing as an entrepreneurial learning process
}

\author{
University West, \\ Economics and IT, Gustava Melins v2, \\ 46186, Trollhattan, Sweden \\ E-mail: stefan.lagrosen@hv.se \\ E-mail: pernilla.josefsson@hv.se \\ *Corresponding author
}

Stefan Lagrosen* and Pernilla Josefsson

\begin{abstract}
The purpose for this paper is to explore social media marketing from the perspective of entrepreneurial learning. The theoretical basis consists of contributions from the fields of organisational learning and entrepreneurship. An empirical study involving ten companies has been carried out. The data were analysed with methods inspired by grounded theory. Categories describing the companies' social media presence from an entrepreneurial learning perspective are provided. The value of using organisational learning as a framework for social media marketing is shown. Thus, the paper presents a novel way of studying social media activities which should contribute to the theoretical fields of organisational learning and entrepreneurship as well as to the understanding of social media marketing. For practitioners, the findings provide additional knowledge that should be useful for their own social media activities.
\end{abstract}

Keywords: social media; entrepreneurship; organisational learning; marketing communication; grounded theory; relationship marketing; entrepreneurial learning; systems thinking; social networking; microblogging.

Reference to this paper should be made as follows: Lagrosen, S. and Josefsson, P. (2011) 'Social media marketing as an entrepreneurial learning process', Int. J. Technology Marketing, Vol. 6, No. 4, pp.331-340.

Biographical notes: Stefan Lagrosen holds a PhD in Business Administration from Stockholm University. He is currently active as a Professor of Marketing and Quality Management at University West, Sweden. He teaches all areas of marketing as well as quality management. His main research interests are quality management in public services, international aspects on quality management, health marketing, work-related health as well as the use of internet and social media in marketing.

Pernilla Josefsson is currently active as a $\mathrm{PhD}$ student at The Royal Institute of Technology, as well as lecturing in media informatics at University West, Sweden. Her specialties are in the areas of social media, graphics and design. Her main research interest is in media technology with a focus on e-learning and social media.

This paper is a revised and expanded version of a paper entitled 'Social media marketing as an entrepreneurial learning process' presented at 4th Euromed Conference, Crete, 2011. 


\section{Introduction and purpose}

The advent of social media has changed the marketing landscape in a profound way. Conducting marketing in social media carries many opportunities but it may also entail many difficulties. As developments in the social media are very fast, many companies are uncertain as to have they should act. A major difference between many traditional marketing communication tools and social media is that the latter builds on interaction. Consequently, an ability to handle relationships is vital. In general, relationship marketing builds on factors such as trust, commitment and attraction (Gummesson, 1999). These factors become even more vital when companies can be in constant interaction with their customers while the customers have ample opportunities to interact between themselves.

Interaction between companies and customers can be seen as a mutual learning process. Companies have excellent opportunities for learning about their customers' needs and wants as well as providing useful information for their customers. If companies pay attention on this, a more profound learning may take place in which the organisation as a whole is developed. This in turn may be a basis for entrepreneurial activities. Successful entrepreneurship requires an ability to find new opportunities in the market or even create a new value balance in the market (Hills and Hultman, 2006). An in-depth learning about customers' needs and wants can enable them entrepreneurs to develop offers that better satisfy customers, thus leading to marketing success. Outside assistance in the learning process has been found to be a success factor for entrepreneurs (Tipu and Arain, 2011). Profound learning in organisations is studied in the field of organisational learning (Argyris, 1999). By applying this theoretical field to the field of entrepreneurship a vantage point for studying entrepreneurial learning could be created.

The purpose for this paper is to explore social media marketing from the perspective of entrepreneurial learning. An empirical study, involving ten companies of different size and industry has been carried out. The findings are analysed from an entrepreneurial learning perspective.

The rest of this paper is structured as follows. First, we present the theoretical bases for the study, i.e., social media marketing, organisational learning and entrepreneurial learning. Second, our methodology and the findings that it generated are described. Third, the analysis is made and conclusions are drawn.

\subsection{Social media and marketing}

Social media in itself is a widely described term, and there are many who try to define it. In general, social media is considered to include a new layer to information. The technologies associated with social media offering services such as, search functions, analytics and social networking (O'Reilly and Battelle, 2009). These services described in social media is said to have revolutionised our social contacts not only in everyday life although privacy issues related to, e.g., the use of cookies are often overlooked (Pierson and Heyman, 2011).

The use of social media has also become more and more popular as a marketing tool for the establishment and management of customer relationships as it offers for an example marketing principles as to influence a specific target of audience, based on voluntarily acceptance as well possibilities for addressing social issues (Kotler et al., 2002). Moreover, new influencers can be identified on social media allowing companies 
to focus their communication more effectively (Booth and Matic, 2011). According to the traditional marketing paradigm, marketing is seen according to the one-way interaction model, where the producer is the sender and the customer is the receiver (Gummesson, 2004). In contrast, the use of social media in marketing is based on a multi-way interaction approach, in which the roles of sender and receiver are mixed (Ström, 2010). A pull marketing strategy is more efficient for the use of social media than the traditional push-marketing approach. This means that the producer uses social media for the communication of information, knowledge, values and ethics related to the service or product, in order to entice the customer to interact. When the customer is interested in taking part in the interaction, valuable information about interests, preferences and values could be interchanged in an informal process and affect the further customer relationship and marketing activities in order to make the product or service more attractive. Ethics and values are important aspect of the interaction, as they could contribute to mutual trust in the relationship building (Brown, 2005).

The combination of the use of different social media could also reinforce the marketing effects. Social media can be an economic alternative especially for entrepreneurs and smaller businesses, as low costs are needed, apart from working hours. Nevertheless, many companies have not yet realised the potential of social media and even those who use them often do it in an inconsistent way (Burton and Soboleva, 2011).

\subsection{Organisational learning}

In order to survive in a competitive context organisations need to constantly develop. Thus processes of learning throughout the organisation are necessary. Organisational learning theories have been developed in order to provide a more sustainable perspective on organisational success. One aspect that is of particular importance for organisational learning is the leaning of leaders and their learning is related to their emotional intelligence (Goleman et al., 2002; Grewal and Salovey, 2005). Emotional intelligence has been defined as the ability to conduct emotional self-leadership and it is related to intra-psychic and intra-personal function (Mayer et al., 1991). The learning of the leaders will be more effective if their emotional self-awareness, one of the dimensions of emotional intelligence, is high (Goleman et al., 2002).

A learning organisation is characterised by people learning together and thereby developing new and expansive patterns of thought which in turn leads to better results (Senge, 1990). Achieving this is related to values such as trust and common visions being present in the organisation (Senge et al., 2005; Senge, 2006). From a social constructivist perspective organisations are seen as having no objective existence; rather they are enacted constructions of the interacting organising parties (Weick, 1979). Assuming this line of thought organisational learning becomes a way of actually constructing organisations.

Moreover, Senge et al. (2005) define different levels of learning. The more profound levels require awareness of a greater wholeness. In order for learning to be profound, the organisational values must be influenced (Argyris, 1993; Argyris and Schön, 1996).

Perhaps, the most influential framework in organisational learning theory is the five disciplines presented by Senge (2006): 
- Personal mastery: There are two aspects of personal mastery as a discipline:

1 Continually clarifying what is important to us. We need to approach our lives as creative work directed towards higher ideals.

2 Seeing current reality more clearly. Many organisations and people live in a self-made web of illusions. Breaking out of this trap is a process of learning.

- Mental models: Our behaviour is usually unconsciously controlled by deeply held internal images of the world around us. These images tend to limit our thoughts and actions to areas that are familiar. Therefore, clarifying these assumptions is a first step towards change. This requires us to slow down our thinking processes so as to become aware of the mental models that they are built on.

- Shared vision: A shared vision is a vision that people throughout the organisation carry. Having impressive power, it can be viewed as a force in people's hearts. As such it provides focus and energy for learning. Achieving a shared vision may be difficult but it can lead to profound organisational learning.

- $\quad$ Team learning: If the energies of the members in a team are aligned, striving in the same direction, their effect is extremely powerful. However, the individual members often have different ambitions and priorities which leads to waste of energy. Aligning the team requires dialogue and deep listening between members.

- Systems thinking: This is the discipline which contains the main argument of Senge. It integrates and forms the basis for the other four disciplines, implying that organisations should be seen as open systems in which all parts constantly interact with each other and with the environment. This is a holistic viewpoint seeing deeper patterns which enable sustainable solutions. Moving away from the traditional reductionist linear way of analysis, the fifth discipline is built on a language of circles including feedback loops where all influences can be both causes and effects.

Consequently, systems thinking is the main basis for organisational learning. Systems thinking is an established feature of organisational theory, going back at least to the original theories regarding a general systems theory by von Bertalanffy (1950). The merits of Senge's contribution lie in establishing systems thinking in relation to organisational learning which should be particularly useful for studying organisational change. The systems view can be used to identify system archetypes, generic families of problems, focusing on which leads to more holistic changes than focusing on specific problems (Gillies and Maliapen, 2008).

\subsection{Entrepreneurial learning}

Entrepreneurship has become popular as a solution to many of the world's current problems. One way of succeeding as an entrepreneur is by finding unexplored niches in markets where all actors have incomplete and often inaccurate information (Kirzner, 1979). Another way is to radically alter the balance of the market by inventing new products, processes, channels, etc. This leads to what can be called creative destruction in that the old order is destroyed in the process that something new and more effective is created (Schumpeter, 1934). Both these processes have obvious implications for learning. 
Entrepreneurial learning needs to be active leading to the acquisition of entrepreneurial patterns rather than just experiences and skills (Wing Yan Man, 2006).

\section{Methodology}

An empirical study has been carried out. Since the study is of an explorative character we chose to use qualitative methods for data collection. A multiple case study was chosen and ten companies were chosen for investigation. The selection was based on theoretical sampling (Glaser and Strauss, 1967). Accordingly, companies and respondents were selected based on their perceived ability to contribute to the theoretical understanding being developed. For this reason the range of companies is very diverse spanning many different industries and ranging from one-man companies to very large enterprises. A list of the companies is provided in Table 1.

Table 1 The companies included in the study.

\begin{tabular}{|c|c|c|}
\hline Company & Type of company & Comments \\
\hline Anonymous & $\begin{array}{l}\text { Photography and } \\
\text { journalism }\end{array}$ & A free-lance photographer and journalist \\
\hline Arena Älvhögsborg & Real estate, healthcare & $\begin{array}{l}\text { A real estate company focusing on facilities } \\
\text { for healthcare, fitness and sports }\end{array}$ \\
\hline Fregatten Atletica & Fitness centre & $\begin{array}{l}\text { A fitness centre offering gym facilities as well } \\
\text { as a wide range of training classes }\end{array}$ \\
\hline Kurortsstaden & SPA-company & $\begin{array}{l}\text { A separate SPA-company that collaborates } \\
\text { with a major hotel }\end{array}$ \\
\hline Marknad Varberg & Networking company & $\begin{array}{l}\text { A company aimed at developing the business } \\
\text { and society in the town of Varberg }\end{array}$ \\
\hline SATS & Fitness chain & $\begin{array}{l}\text { The largest fitness chain in Scandinavia with } \\
116 \text { fully owned fitness centres }\end{array}$ \\
\hline Sports international & Sports arrangements & $\begin{array}{l}\text { A small company that arranges cups, voyages } \\
\text { and other events }\end{array}$ \\
\hline Statens järnvägar & Railway operator & $\begin{array}{l}\text { Sweden's main railway operator. State owned } \\
\text { but competes in a market with private actors. }\end{array}$ \\
\hline Stena Fastigheter & Real estate & $\begin{array}{l}\text { One of Sweden's largest real estate companies } \\
\text { focusing on private tenants }\end{array}$ \\
\hline Strömstads Badanstalt & Spa and fitness centre & $\begin{array}{l}\text { A company offering baths, SPA-treatments } \\
\text { and fitness activities. }\end{array}$ \\
\hline
\end{tabular}

In-depth interviews (Patton, 1990), were carried out with managers responsible for marketing communications in the companies. In depth qualitative research has been found to be superior to social media monitoring even when studying social media activities (Branthwaite and Patterson, 2011). In total, eleven interviews were carried out by students trained by the authors. The interviews were of a conversational character. No fixed questionnaire was used. Instead the respondents were encouraged to speak freely from their own hearts so as to not superimpose the presuppositions of the authors on the respondents. The data from the interviews was analysed by the authors based on methods inspired by the constant comparative technique from the grounded theory approach (Glaser and Strauss, 1967; Glaser, 1992). 


\section{Findings}

The analyses of the interviews revealed the following categories:

\subsection{Use}

This category concerns the level to which they use social media and which media they use. Several companies use social media to a rather low extent. Some others use it much more. The varying degrees of use do not seem particularly related to the size of the organisation. The largest organisations are the most active users but some of the very small companies are also very active. From this small sample it seems to be the medium sized companies that lag behind. Regarding the choice of social media tools, all companies currently use Facebook (networking site) which seems to be the completely dominating tool. A few of the companies also use Twitter (microblogg service), YouTube (video sharing site) and blogs. One company also uses Scribd (a publishing site) and LinkedIn (networking site). Interestingly, although all the companies use Facebook, they have adopted it lately. Thus, those companies that use Twitter began using it before they entered Facebook. Concerning the companies' use and adoption of microblogging, this application allows and meets a need of regular and fast communication, which requires less time investment from the user (Java et al., 2007; Naaman et al., 2010).

\subsection{Aims and results}

The aim that most companies emphasise is providing information for their customers. The information can be of concrete nature informing current customers about changes in services, delays, problems or new procedures. Alternatively, the media are used for more traditional selling messages intended to push products. Nevertheless, some companies are eager to promote an active dialogue with the customers and in a few cases also between the customers. Certain companies have noticed a need from the customers to communicate between each other. In addition, such possibilities are believed to make the customers more committed to the companies and their products.

There seems to be an almost linear development in the ambitions of the companies, going from fairly traditional one-way communication to encouraging an active dialogue; and finally to aim for a community of interacting customers and prospects. Regarding the media, there is also a difference in that microblogging is seen more as a tool for one-way communication while social networking sites are perceived to be more interactive. Facebook for example is also regarded as more private and intimate whereas Twitter is thought to be more as a business like information media.

When this living dialogue is achieved, it is seen as a learning process in which feedback from the customers is used for developing the companies' offers. In this way, companies can get fast and direct knowledge regarding developments in the market. It is also seen as a wider environmental analysis tool. Active response from customers is sometimes stimulated by contests and special offers for social media contacts.

The information giving is also seen as a kind of education process for the customers. In particular, one company uses YouTube as a channel for conveying knowledge about fitness activities and news in the health area. For this purpose, they have started their own YouTube channel. Moreover, the companies link Facebook visitors to their homepage on the web where they can provide more information. 
By answering to criticism the companies are able to provide their view and explain their activities. They can react to critical tendencies very quickly. Sometimes satisfied customers 'defend' the companies against criticism which is very valuable due to their much higher credibility. Moreover, they regard social media presence as a way as giving additional service to customers using it as an 'online customer service centre'.

\subsection{The image factor}

From the interviews, it was clear that several companies have more than just concrete aims for their social media presence. They see presence on social media as a way of seeming to be modern and up to date. Thus, social media presence in itself is viewed from a branding perspective. Nonetheless, they realise that their social media pages must be updated and active in order not to give an amateurish impression. In addition, companies that are active in company networks need to coordinate their different social media activities so as to not confuse customers and public.

\subsection{Uncertainty}

There is a substantial uncertainty among the companies regarding their media presence. They have difficulties in assessing the costs. The direct costs are normally very low. On the other hand, the time it takes for employees to work with the social media presence entails substantial costs that are hard to gauge since the same employees often work with many different tasks at the same time. Measuring the effects of the presence is even more difficult. Only a few very basic things, like the number of followers on Twitter or the number of likes on Facebook is immediately quantifiable. Sometimes they can also get a feeling for the power of the media by providing special offers only available through social media and measuring how many customers take advantage of them. In appreciating other effects, the companies usually have to be content with mere guesswork. This makes it problematic to decide how much to invest in social media presence and which activities to engage in. In addition, they are uncertain as to how they should handle criticism or abusive behaviour on the social media. All in all, this uncertainty was rather marked and troubling for the companies. The consequence is that most of the companies in this study do not have any specified aims for their social media presence and the activities are often the result of ad-hoc decisions.

\subsection{Connection to organisational learning}

In order to assess the connection of these findings to organisational learning, we chose to relate them to the five disciplines framework of Senge (2006) presented above. This lead to the following inferences:

- Personal mastery: Used in a suitable manner social media should give organisations a possibility of seeing their reality more clearly. Many organisations have lacking understanding of the experiences, attitudes and feelings of their customers and other publics. By promoting interaction with and among social media users, as some of the respondents did, they may begin to see their organisation in a new light. 
- Mental models: If a profound dialogue on social media is achieved the limits set by organisations' mental models may be widened. Nevertheless, this also requires slowing down the thinking process in order to reflect. The studied companies reported that working with social media can require substantial input of time from the employees. If this time is spent in too superficial information handling the opposite of this discipline might result.

- Shared vision: A shared vision need to be built on dialogue which is respectful and profoundly focuses on learning to understand other people's viewpoints. Interaction on social media could ameliorate such learning. Nevertheless, this again requires the social media interaction to be of a more profound nature than it was for most of the companies included in the study.

- Team learning: Aligning the team requires dialogue and deep listening between members. Is this deep listening possible on social media? If so this could be a way of forming aligned teams. This should be an important issue for further research to examine.

- Systems thinking: Based on the interviews, we can conclude that those companies that use social media most successfully have managed to integrate them into a larger system. This reduces the uncertainty that many companies experience. Using social media as a separate addition without connection to the other activities of the company will not lead to any useful results. Instead, their role in the greater open system, that includes the company, the customers and other stakeholders of importance, should be assessed. By utilising social media in this context as a means of gaining profound knowledge as noted above, they could become a very useful tool for entrepreneurial learning as well as for entrepreneurial success.

\subsection{Conclusions}

We have seen that the use of social media varies substantially between the companies. Those who use them most successfully have managed to stimulate interactivity and put them into a larger context. Viewing the findings of the study through the lens of the five disciplines of the learning organisation (Senge, 2006) provided additional understanding. The importance of achieving a profound dialogue and handling social media in the context of the larger system became clearer. The contribution of this study lies in the understanding of companies' actual use of social media that has been presented in the previous section as well as the realisation of the value of using an organisational framework as a vantage point for developing more profound and effective social media marketing.

\subsection{Suggestions for further research}

This is a first, limited study of an explorative character involving a small number of companies. It provides some preliminary knowledge that can be used for more in-depth research. For future research, larger studies involving many companies and going more into detail regarding success factors and hurdles should be welcome. 


\section{Acknowledgements}

The authors would like to thank the students for their professional performance of the interviews with the company representatives.

\section{References}

Argyris, C. (1993) Knowledge for Action, A Guide to Overcoming Barriers to Organizational Change, Jossey-Bass Publishers, San Francisco.

Argyris, C. (1999) On Organizational Learning, Blackwell, Oxford.

Argyris, C. and Schön, D.A. (1996) Organizational Learning II, Theory, Method, and Practice, Addison-Wesley Publishing Company, Reading.

Booth, N. and Matic, J.A. (2011) 'Mapping and leveraging influencers in social media to shape corporate brand perceptions', Corporate Communications: An International Journal, Vol. 16, No. 3, pp.184-191.

Branthwaite, A. and Patterson, S. (2011) 'The power of qualitative research in the era of social media', Qualitative Market Research: An International Journal, Vol. 14, No. 4, pp.430-440.

Brown, J. (2005) The World Café - Shaping Our Futures Through Conversations That Matter, Berrett-Koehler Publishers Inc., San Francisco.

Burton, S. and Soboleva, A. (2011) 'Interactive or reactive? Marketing with Twitter', Journal of Consumer Marketing, Vol. 28, No. 7, pp.491-499.

Gillies, A. and Maliapen, M. (2008) 'Using healthcare system archetypes to help hospitals become learning organisations', Journal of Modelling in Management, Vol. 3, No. 1, pp.82-99.

Glaser, B.G. (1992) Basics of Grounded Theory Analysis, Sociology Press, Mill Valley, CA.

Glaser, B.G. and Strauss, A.L. (1967) The Discovery of Grounded Theory, Strategies for Qualitative Research, Aldine Publishing Company, Chicago Il.

Goleman, D., Boyatzis, R. and McKee, A. (2002) Primal Leadership, Realizing the Power of Emotional Intelligence, Harvard Business School Press, Boston.

Grewal, D. and Salovey, P. (2005) 'Feeling smart: the science of emotional intelligence', American Scientist, Vol. 93, No. 4, pp.330-339.

Gummesson, E. (1999) Total Relationship Marketing, Butterworth-Heinemann, London.

Gummesson, E. (2004) Many-to-Many Marketing, Liber, Stockholm.

Hills, G.E. and Hultman, C.M. (2006) 'Entrepreneurial marketing', in Lagrosen, S. and Svensson, G. (Eds.): Marketing - Broadening the Horizons, Studentlitteratur, Lund.

Java, A., Song, X. and Tseng, B. (2007) 'Why we twitter: understanding microblogging usage and communities', 9th WebKDD and 1st SNA-KDD 2007 Workshop on Web Mining and Social Network Analysis, ACM, San José, CA.

Kirzner, I.M. (1979) Perception, Opportunity and Profit - Studies in the Theory of Entrepreneurship, University of Chicago Press, Chicago.

Kotler, P., Roberto, N. and Lee, N. (2002) Social Marketing, Improving the Quality of Life, Sage Publications Inc., Thousand Oaks, CA.

Mayer, J.D., Salovey, P., Gomberg-Kaufman, S. and Blainey, K. (1991) 'A broader conception of mood experience', Journal of Personality and Social Psychology, Vol. 60, No. 1, pp.100-111.

Naaman, M., Boase, J. and Lai, C-H. (2010) 'Is it really abour me?: message content in social awareness streams', 2010 ACM Conference on Computer Supported Cooperative Work, ACM, New York, NY.

O'Reilly, T. and Battelle, J. (2009) 'Web squared: web 2.0 five years on', Special report, O'Reilly Media, Inc. and TechWeb.

Patton, M.Q. (1990) Qualitative Evaluation Methods, Newbury Park Ca., Sage Publications. 
Pierson, J. and Heyman, R. (2011) 'Social media and cookies: challenges for online privacy', Info, Vol. 13, No. 6, pp.30-42.

Schumpeter, J.A. (1934) The Theory of Economic Development, Harvard University Press, Boston.

Senge, P.M. (1990) The Fifth Discipline, the Art \& Practice of the Learning Organization, Random House Business Books, London.

Senge, P.M. (2006) The Fifth Discipline: the Art and Practice of the Learning Organization. Currency Doubleday, New York.

Senge, P.M., Scharmer, C.O., Jaworski, J. and Flowers, B.S. (2005) Presence, Exploring Profound Change in People, Organizations and Society. Nicholas Brealey Publishing, London.

Ström, P. (2010) Sociala medier: gratis marknadsföring och opinionsbildning, Liber, Malmö.

Tipu, S.A.A. and Arain, F.M. (2011) 'Managing success factors in entrepreneurial ventures: a behavioral approach', International Journal of Entrepreneurial Behaviour \& Research, Vol. 17, No. 5, pp.534-560.

von Bertalanffy, L. (1950) 'An outline of general systems theory', British Journal of the Philosophy of Science, Vol. 1, No. 2, pp.139-164.

Weick, K.E. (1979) The Social Psychology of Organizing, Addison-Wesley Publishing Company, Reading.

Wing Yan Man, T. (2006) 'Exploring the behavioural patterns of entrepreneurial learning, a competency approach', Education and Training, Vol. 48, No. 5, pp.309-321. 